LOVRO MAGLIĆ, Ph.D.

E-mail: maglic@pfri.hr

DAMIR ZEC, Ph.D.

E-mail: zec@pfri.hr

VLADO FRANČIĆ, Ph.D.

E-mail: vfrancic@pfri.hr

University of Rijeka,

Faculty of Maritime Studies

Studentska 2, 51000 Rijeka, Croatia
Traffic and Environment (Ecology)

Preliminary Communication

Submitted: Apr. 7, 2015

Approved: Oct. 6, 2015

\title{
EFFECTIVENESS OF A BARGE-BASED BALLAST WATER TREATMENT SYSTEM FOR MULTI-TERMINAL PORTS
}

\begin{abstract}
The paper presents outcomes of the discrete event simulation of the ballast water management in a multi-terminal port. The simulation includes ship's manoeuvring, cargo and ballast operations and a barge-based ballast water treatment system operating within all terminal areas. The barge-based ballast water treatment system is used by ships unable to use their own equipment, not equipped with an appropriate ballast treatment system or non-compliant with the Ballast Water Management (BWM) Convention 2004 for whatever reason. The main goal is to estimate the productivity and cost effectiveness of such systems as an option to support ships not able to comply with the BWM Convention, once it enters into force. The model was built and tested in Arena simulation software. Process parameters are based on real traffic data for the port of Rijeka. The results indicate that barge-based ballast treatment facility will be heavily underutilized, and that such systems are cost-effective only in ports where large volumes of ballast water need to be delivered to shore treatment systems.
\end{abstract}

\section{KEY WORDS}

ballast water management; ballast reception facility; discrete event simulation;

\section{INTRODUCTION}

The transfer of harmful organisms and pathogens across natural barriers has been recognized as one of the greatest threats to the world's oceans and seas, causing global environmental changes, and posing threat to human health, property and resources [1]. Ballast water transfer by ships was recognized as a prominent vector for movement of such species and was regulated by the International Convention for the Control and Management of Ship's Ballast Water and Sediments, 2004 (BWM Convention). The BWM Convention sets the global standards on ballast water management (BWM) requirements, while recognizing that regional and local specifics have to be considered for its effective implementation [1].

According to the BWM Convention, ballast water management is primarily based on ships, i.e. ballast water exchange as per D-1 standard and ship-board treatment technologies as per D-2 standard, but portbased technologies may also be used to comply with the D-2 standard [2].

Port-based technologies can be divided into:

- Land-based reception systems - a ballast water treatment (BWT) plant is located ashore and connected with terminals by pipeline system.

- Land-based mobile systems - a BWT plant is loaded on a truck or a similar vehicle and moved in the vicinity of the ship requiring service.

- Barge-based reception systems - a BWT plant is located either on the barge (with or without its own propulsion) or a barge is used to accept ballast from ships and transfer it to land-based facility.

The study by Brown and Coldwell in 2007 [3] is the first known study completely devoted to port-based ballast water treatment. In this study several different technologies and implementation options, including some quite radical approaches, have been investigated. Based on the cost and access options the study concluded that the most convenient port-based BWT system is the one using a barge with plant installed onboard. The same research group continued the study in 2008 [4] focusing on the barge-based ballast water treatment system. The study examined the necessary retrofitting of ships as well as the main characteristics of the barge and water treatment technology that may be used on board barge.

The study prepared in Denmark in 2012 [5] investigates the possibilities and feasibility of the port-based ballast water treatment by mobile units. The study has been based on two Danish ports and includes several 
scenarios and business cases, mainly involving freight ferries and ships in regular service. The study concluded that barge-based systems are feasible but may result in rather high costs.

In 2013 King and Hagan [6] investigated economic and logistical feasibility of shore-based BWT at the port of Baltimore (USA). The authors assumed that potential users of such a facility would be ships without a USCG approved on-board BWT system. It is concluded that economic viability of shore-based systems significantly depends on circumstances prevailing in the particular port and may vary from very positive outcomes up to very negative ones.

According to the previously mentioned research and others $[7,8,9]$ the most relevant conclusions on barge-based system are summarized hereafter.

The most important advantages of barge-based systems are:

- ability to be used on different locations, including anchorage;

- possibility to use systems that are not viable on land (e.g. insufficient power supply on land or limited space on land);

- possibility of use without land-based pipelines;

- employment of qualified crew members operating the barge and the BWT system.

The main disadvantages of the use of barge are:

- number and frequency of ships discharging ballast water per terminal may be significantly below the economic threshold;

- additional costs are required for barge fuel, oil and maintenance;

- less optimal operations are inevitable - if low capacity system is installed, delays may be encountered by high ballast dependent ships; if high capacity systems are employed the system will be rarely fully utilized;

- potential delays could be expected due to concurrent requests or in case of barge failure.

Croatia has ratified the BWM Convention and the Maritime Authorities are in the process of preparation to comply with it as soon as it enters into force. There is already in force the national Ordinance on ballast water management and control (Official Gazette $55 / 07,128 / 12)$. However, the only implemented mandatory measure for ships arriving in Croatian ports is issuing the Ballast water reporting form. In Croatian ports there are no port-based ballast water treatment facilities whatsoever.

In order to obtain information on the usefulness of the barge-based BWT system, a discrete event simulation of port maritime traffic has been developed using the Arena simulation software. The complete port traffic is simulated, including arrivals of ships in a multi-terminal port, cargo loading and unloading operations, usual off-trade time of ships and ballast operations during loading/unloading operations. It is assumed that ships arriving in the port include the most common types of merchant ships, either passenger or cargo.

Ballast discharge operations are simulated as a part of regular port operations assuming that ships use either on-board installed BWT systems or BWT barge. The BWT barge is used by ships not able to comply with the BWM Convention requirements or ships not equipped with appropriate BWT system.

The main goals were to estimate the following for the given port:

- total number and frequency of ships discharging ballast water per terminal;

- total volume of discharged ballast water per terminal;

- volume of ballast water discharged and treated using BWT barge;

- performance of BWT barge, mostly the frequency and time used;

- ship's delays due to unavailability of BWT barge.

Taken together, the overall aim was to confirm whether it is economically and organizationally reasonable to use a BWT barge as an additional service offered to ships.

\section{EXPERIMENT DESIGN}

\subsection{Basic assumptions}

The model developed for the simulation purposes is based on several assumptions, the most important being:

- Ships comply with BWM convention.

- Certain number of ships arriving at port is not compliant with the BWM Convention or unable to conduct an appropriate BWM procedure (ships with inoperative on-board BWT system, ships that did not exchange ballast water or ships that have not installed BWM system on board). These ships have to use BWT barge service.

- BWT barge services are assigned on the "firstcome-first-served' principle. The trigger for assignment is ship's request.

Assumptions describing traffic at the terminals are as follows:

- Port consists of pre-defined number and types of terminals. Positions of terminals and type of ships commonly accommodated are known and static.

- Terminal capacities are known and static. Capacities are used to determine the maximum number of ships at the terminal at the same time.

- Proportion of ships discharging ballast water is arbitrarily selected and static. The ship discharging ballast water in the port is randomly selected among ships arriving in port. 


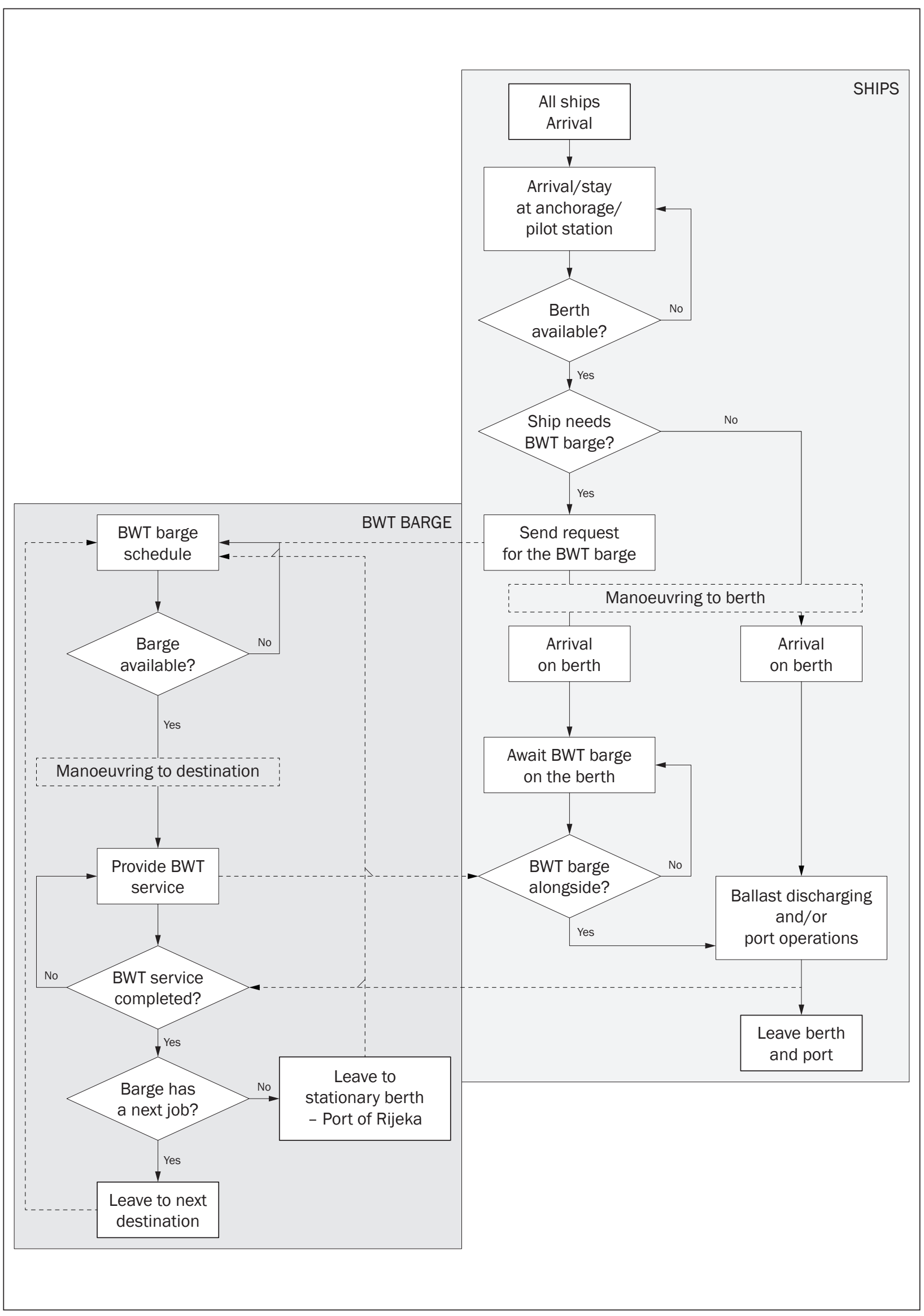

Figure 1 - Simulation dynamics 
- Proportion of ships requesting BWT barge services is arbitrarily selected and static. The ship requiring BWT barge in the port is randomly selected among ships discharging ballast water in port.

- Cargo difference is defined as difference between loaded and unloaded quantities of cargo. It is expressed using uniform distribution and defines the volume of discharged ballast.

For each terminal the following parameters are defined:

- Time between arrivals is based on overall statistics for the whole port.

- Manoeuvring times (from pilot station/anchorage to terminal and vice versa) are estimated for each terminal on real-life data.

- Port times (the time the ship is berthed alongside) are estimated for each terminal on average loading/unloading rates.

- The values of cargo on board are estimated on average ships' size usually being accommodated at particular terminal.

For the BWT barge the following parameters are assumed:

- Ballast treatment unit capacity $\left[\mathrm{m}^{3} / \mathrm{h}\right]$ is known and static. It is assumed that the treatment time is malfunction-free.

- Sailing speed [kts] is known and static. The value is comparable with speeds common for barges usually operated within port environments.

- Position of lay-up berth is known and static. It is assumed that only one lay-up position is assigned.

\subsection{Simulation dynamics}

Simulation dynamics describes movements of different objects in the system. Ships are temporary objects (entities); they arrive, wait for berth, load/unload cargo and passengers and then leave the system. There is only one BWT barge created, as a special object (transporter), at the beginning of the simulation and exists during the entire simulation time.

The objects move from one location to another following the rules as described:

- Ship arriving in the port arrives at the designated anchorage and waits until available berth on respective terminal has free capacity.

- Ship not requiring BWT, upon receiving the notice that berth is available, manoeuvres from the anchorage to the berth at destination terminal.

- Upon completing ballast and port operations the ship is leaving the port.

- Ship requiring BWT barge, upon receiving the notice that the berth is available, sends request to barge to proceed to the ship's terminal. The ship concurrently manoeuvres from the anchorage to its berth.
- After being berthed the ship requiring BWT awaits the BWT barge. Once the barge is alongside, discharging of ballast and port operations may start. Upon completion of ballast discharge, the ship continues with port operations if required.

- In the case that BWT barge arrives at the requested terminal before the ship, it awaits until the ship is berthed.

- Once the ballast operations are completed the BWT barge is released and it proceeds to the next requested destination.

- If the BWT barge does not have a next assignment it proceeds to its lay-up berth.

Ships already berthed found non-compliant with the BWM Convention are not considered because in simulation they do not change the occupational time of the barge and BWT unit working time. It is estimated that such events should not occur frequently.

It is worthwhile to emphasize that any port that can be described in line with the mentioned assumptions can be easily modelled using the developed logic.

\section{CASE STUDY - PORT OF RIJEKA}

Based on the described conceptual model, an actual simulation instance for the port of Rijeka has been developed using Arena software (PC performance: CPU i7 of 3.6 GHz, RAM 8 GB DDR3, HDD 1TB SATA).

Arena is simulation software developed by Rockwell Automation Inc., and uses the SIMAN process language. It is used to simulate system behaviour as a discrete sequence of events in time. In Arena an experiment model is built using modules which represent a process or a specific logic. Interconnected modules define the flow of entities i.e. the basic elements that may be created, moved through the model causing changes in the system, and acted on by any process during the simulation. Other important elements include Resources and Transporter. Resources are elements that are seized by entities for a certain time in order to carry out a required activity, and transporters are elements required for entity transport. Additionally, transporters can be used to simulate movement from one location to the other.

In this experiment the main elements are defined as follows:

- Entities represent ships arriving in port terminals;

- Resources represent terminal berths and the ballast treatment unit on a BWT barge, and

- Transporter represents the BWT barge.

Input parameters are a series of information defining states or conditions and different entity features. Inputs for this experiment include terminal and ship parameters. 
Table 1 - Terminal parameters - port of Rijeka

\begin{tabular}{||c|c|c|c|c|c||}
\hline No. & Terminal & Ship Type & $\begin{array}{c}\text { Terminal } \\
\text { capacity } \\
C_{t} \in \mathbb{N}\end{array}$ & $\begin{array}{c}\text { Quota of ships } \\
\text { disch. ballast } \\
b_{d} \in\{0,1\}\end{array}$ & $\begin{array}{c}\text { Cargo } \\
\text { difference } \\
E X_{c} \in \mathbb{R}^{+}[\mathrm{t}]\end{array}$ \\
\hline \hline 1. & Port of Rijeka & General cargo & 9 & $67 \%$ & $50-50,000$ \\
\hline 2. & Port of Sušak & General cargo & 3 & $67 \%$ & $50-16,500$ \\
\hline 3. & Port of Bakar & Bulk/Product tanker & 4 & $65 \%$ & $75-36,500$ \\
\hline 4. & Container Terminal Brajdica & Container & 2 & $21 \%$ & $30-6,000$ \\
\hline 5. & JANAF Oil Terminal Omišalj & Oil tanker & 2 & $2 \%$ & $50-30,000$ \\
\hline 6. & LPG terminal Sršćica & LPG carrier & 1 & $80 \%$ & $50-2,000$ \\
\hline 7. & Shipyard “Viktor Lenac" & Miscellaneous & 8 & $100 \%$ & $\mathrm{~N} / \mathrm{A}$ \\
\hline 8. & Terminal Raša Bršica & General cargo & 4 & $92 \%$ & $250-5,500$ \\
\hline \hline
\end{tabular}

\subsection{Terminal and ship parameters}

Terminal parameters are parameters describing traffic output to be expected at each terminal. For the simulation purpose, terminals are defined as a group of berths having similar characteristics (depth, approach waterways, modes of berthing, types of cargoes, types of ships, loading/unloading technologies).

Terminal capacity represents the number of operational berths. Ships discharging ballast $\left(b_{d}\right)$ are determined by the number of ships whose cargo loaded exceeds unloaded cargo. For those ships the Cargo difference $\left(E X_{c}\right)$ is determined by subtracting unloaded from loaded cargo (in tons).

Cargo difference values are distributed uniformly between range limits.

For the shipyard "Viktor Lenac" cargo difference is not calculated since it is assumed that all ships arrive with no cargo on board. Consequently, all ships arriving in the "Viktor Lenac" shipyard unload ballast. Based on the personal communications with head of the Safety department at the shipyard the ballast volume to be un-

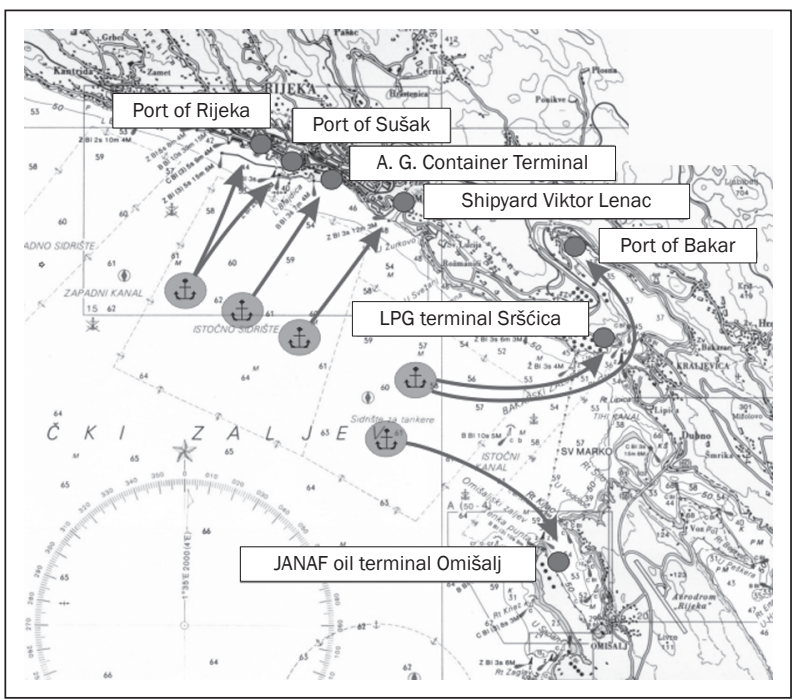

Figure 2 - Rijeka bay - terminal configuration and anchorage stations loaded is estimated at $20 \%$ of ship's deadweight.

Ships (entities) enter the system at the anchorage. When a ship leaves the anchorage the manoeuvring times to the respective terminal are calculated.

The only terminal outside the Bay of Rijeka is the terminal Raša Bršica. It is approximately 35 nautical miles from the Rijeka main port. It is included in the simulation because it is a part of the Rijeka Port Authority system. It is mainly an export port.

Mean arrival time (hours) between two ship arrivals is determined by using the monthly average of ships accommodated in the port. The arrival distribution is simulated using exponential distribution where $t_{a}$ represents the respective mean value.

For the manoeuvring time, operations time and deadweight the smallest, largest, and the most probable values are taken using triangular distribution. The manoeuvring time (hours) is determined as a time span from the moment when the pilot boards the ship until it is alongside. Operation time (hours) is determined as the time between the moment the ship is alongside until pilot comes on board for departure.

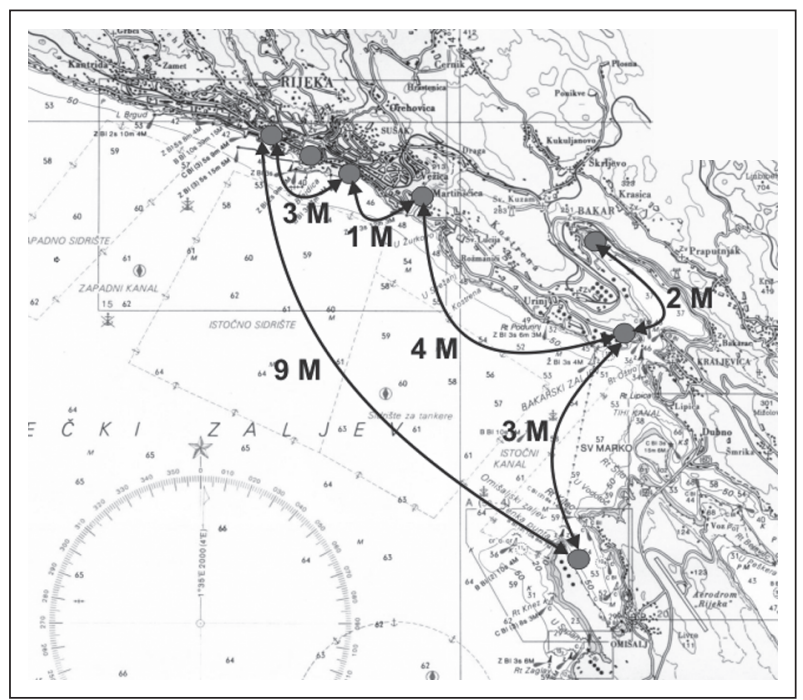

Figure 3 - Rijeka bay - main terminal distances 
Table 2 - Ships parameters

\begin{tabular}{||c|c|c|c|c|c||}
\hline No. & Terminal & $\begin{array}{c}\text { Mean arrival } \\
\text { time } \\
t_{a} \in \mathbb{R}^{+}[\mathrm{h}]\end{array}$ & $\begin{array}{c}\text { Manoeuvring } \\
\text { time } \\
t_{m} \in \mathbb{R}^{+}[\mathrm{h}]\end{array}$ & $\begin{array}{c}\text { Operations } \\
\text { time } \\
t_{0} \in \mathbb{R}^{+}[\mathrm{h}]\end{array}$ & $\begin{array}{c}\text { Deadweight } \\
\text { DWT } \in \mathbb{R}^{+}[\mathrm{t}]\end{array}$ \\
\hline \hline 1. & Port of Rijeka & 28.8 & $0.2-0.3-1.4$ & $5-62-120$ & $2,000-25,000-60,000$ \\
\hline 2. & Port of Sušak & 192 & $0.2-0.3-0.8$ & $4-55-120$ & $2,000-4,000-40,000$ \\
\hline 3. & Port of Bakar & 27.6 & $0.2-0.5-2.3$ & $11-40-76$ & $3,000-20,000-150,000$ \\
\hline 4. & Container terminal Brajdica & 28.5 & $0.2-0.5-1.5$ & $6-15-42$ & $5,000-45,000-100,000$ \\
\hline 5. & Oil Terminal Omišalj & 127.2 & $0.3-2-3.7$ & $5-30-41$ & $35,000-110,000-250,000$ \\
\hline 6. & LPG terminal Sršćica & 342.8 & $0.3-0.5-1.9$ & $8-21-40$ & $3,000-4,000-6,000$ \\
\hline 7. & Shipyard Viktor Lenac & 116.9 & $0.3-0.5-3.6$ & $16-80-195$ & $1,500-60,000-160,000$ \\
\hline 8. & Terminal Raša Bršica & 77.8 & $0.2-0.3-1.3$ & $8-42-110$ & $1,100-4,000-8,000$ \\
\hline
\end{tabular}

All ship parameters are interpolated using data from the Croatian Integrated Maritime Information System (CIMIS) and Port of Rijeka Authority statistics for 2013.

Regarding the barge, the assumed parameters are comparable with service parameters of the BWT barge layout developed by Damen Shipyards Group, the Netherlands. The assumed ballast treatment capacity is $300 \mathrm{~m}^{3} / \mathrm{h}$ and the sailing speed is 8 knots. The barge laid-up position is assumed to be at a terminal in the main port of Rijeka.

\subsection{Simulation logic and ballast calculation}

The model developed is divided into three interconnected logical units:

- Ships arrival and distribution;

- Terminal process, and

- Ballast water treatment process.

Ships arrival and distribution defines the frequency and arrival position for each terminal. Attributes assigned to each ship are DWT, $t_{0}, b_{d}, E X_{c}$ and terminal. Here, the ships movement from the anchorage to its destination is controlled as well as the BWT barge request procedure.

Terminal process for each terminal defines the berth allocation and port operations time. It is assumed that port operations are carried out concurrently with all ballast water operations.

Ballast water treatment process defines the ballast water volumes, BWT barge allocation, ballast water transfer and ballast water treatment procedures.

Ballast water volumes can be estimated according to gross tonnage or deadweight. For various ship types, ballast water capacity has been estimated as averaging 33-84\% of gross tonnage [10]. Ballast water volumes loaded on board in relation to ship gross tonnage is averaging as follows:

- $28-57 \%$ for ships in ballast condition, and

- $3-16 \%$ for ships in loaded condition.

Taking into account ship deadweight, ballast water capacity has been estimated as averaging $32-47 \%$ of deadweight [10]. In other more recent studies it is es- timated at 30-40\% [11]. Ballast water carried on board is estimated at $32-36 \%$ of deadweight for ships in ballast condition and $5-28 \%$ for ships with cargo on-board while discharged ballast water approximates as 1-20\% of deadweight. Ballast water carried on board normally accounts for $25 \%$ of deadweight tonnage, but may be $20 \%$ for ships on short voyages with fair weather conditions, 30\% for heavy weather conditions, and up to $40 \%$ for severe weather conditions. Estimated ballast water carried by bulk carriers is typically estimated at $30-40 \%$ of deadweight, and $40-50 \%$ for heavy weather conditions. Estimates of ballast water volume calculated at $30 \%$ of the deadweight for ships entering with ballast have been considered as a minimum [10].

The usual volume of ballast water carried has been estimated at $6-89 \%$ of ship ballast water capacity, and the volume discharged as $3-46 \%$ of ballast water capacity, over a range of ship types and conditions.

Estimates based on quantity of export cargo take into account the difference in cargo quantities to be loaded. Ballast-to-load ratios (the ratio of ballast water discharged for the purpose of maintaining proper draft to the tonnage of cargo loaded) have been estimated at 0.18 for refrigerated cargo ships of 4,000-11,000 deadweight tons, 0.15-0.25 for container ships, 0.350.40 for bulk carriers of up to 60,000 deadweight tons, and 0.45-0.55 for larger bulk carriers [10].

The prediction of ballast water volumes in this simulation follows the estimation proposed by Suban in [12]. The prediction whether ballast water will be discharged is based on the difference between cargo loaded and unloaded and ships' deadweight. If the cargo to be loaded is greater than the quantity to be discharged by more than $10 \%$ of the ships deadweight then it is assumed that the ballast water discharge $\left(b_{d}\right)$ will be carried out.

In order to properly estimate the operational efficiency of the barge-based ballast water treatment systems two significantly different scenarios have been developed.

The worst case scenario assumes that $10 \%$ of ships will require the BWT barge services and that ballast 
water volume to be discharged $\left(b_{v}\right)$ is proportional to the quantity unloaded by 20,25 and $33 \%$, as follows:

$b_{v}=\left\{\begin{array}{c}E X_{c} \cdot 0.2, \quad 0.1 \leq E X_{c} / D W T<0.5 \\ E X_{c} \cdot 0.25,0.5 \leq E X_{c} / D W T \leq 0.8 \\ E X_{c} \cdot 0.33, \quad E X_{c} / D W T \geq 0.8\end{array}\right.$

The realistic scenario assumes that $5 \%$ of ships will require BWT barge services and that ballast water volume to be discharged is proportional to the quantity unloaded by 10,15 and $20 \%$ (based on the personal communication with port state control officer in port of Rijeka responsible for implementation of national BWM regulations), as follows:

$b_{v}=\left\{\begin{array}{rr}E X_{c} \cdot 0.1, & 0.1 \leq E X_{c} / D W T<0.5 \\ E X_{c} \cdot 0.15, & 0.5 \leq E X_{c} / D W T \leq 0.8 \\ E X_{c} \cdot 0.2, \quad E X_{c} / D W T \geq 0.8\end{array}\right.$

Ships unable to manage ballast water await the arrival of the BWT barge to commence ballast and port operations. The ballast water treatment process on the barge $\left(t_{b t}\right)$ depends on the calculated ship's ballast volume to be discharged, as follows:

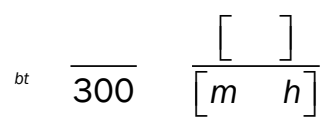

After completion of the treatment process, the barge is moved to the new destination (if another treatment is scheduled), otherwise it sails to the lay-up berth.

\section{RESULTS}

To obtain reliable data, simulation time was set to 3 years or 25,920 hours for the realistic and worst case scenario. The base time unit was 1 minute.

Table 3 - Results of the real case scenario (ships)
Worst case scenario resembles the actual number of ships entering the port. However, the number of ships discharging ballast water is more than three times higher than estimated (based on available data). The discharge quantities, as estimated here, would resemble reality only in case the port becomes primarily a loading port. For example, such circumstances can be expected if two terminals handling bulk cargoes, i.e. Omišalj and Bakar, become exporting ports.

The ratio of ships using the service and waiting for the BWT barge is quite high (53\%). The average waiting time for the barge is $6.2 \mathrm{~h}$. As such, it is unacceptable for most ship operators. It can be downsized if barge-based treatment facility doubles its capacity. The main cause of such long waiting time is the port of Bršica. The sailing time for the barge from lay-up berth is approximately $4.4 \mathrm{~h}$, thus significantly increasing the average waiting time and the number of ships waiting for the barge. Naturally, the average waiting time significantly increases in those rare cases when more than 2 ships concurrently require BWT barge service (totally, 29 occurrences in a three-year period).

It is important to notice that $84.2 \%$ of time the BWT barge is on the lay-up berth. The BWT barge operational time is divided into ballast water treatment process (13.82\%) and navigation (1.96\%).

Realistic scenario assumes that only $5 \%$ of all ships will require the BWT barge service. Also, the volume of ballast water discharged is defined in a much more conservative manner. The number of ships is almost the same $(3,631$ vs. 3,617$)$ due to the same arrival distributions. The number of ships discharging ballast has decreased by almost $9.7 \%$ due to random variability.

\begin{tabular}{|c|c|c|c|c|c|c||}
\hline Terminal & $\begin{array}{c}\text { Ships } \\
\text { arrived }\end{array}$ & $\begin{array}{c}\text { Ships discharging } \\
\text { ballast }\end{array}$ & $\begin{array}{c}\text { Ballast } \\
\text { discharged (t) }\end{array}$ & $\begin{array}{c}\text { Ships using } \\
\text { BWT barge }\end{array}$ & $\begin{array}{c}\text { Ships waiting } \\
\text { for BWT barge }\end{array}$ & $\begin{array}{c}\text { Average } \\
\text { waiting time (h) }\end{array}$ \\
\hline \hline Port of Rijeka & 927 & 629 & $2,303,578$ & 34 & 0 & 0 \\
\hline Port of Sušak & 143 & 86 & 44,395 & 8 & 0 & 0 \\
\hline Port of Bakar & 894 & 577 & $1,371,993$ & 21 & 19 & 0.5 \\
\hline Cont. terminal Brajdica & 817 & 185 & 15,058 & 1 & 0 & 0 \\
\hline Oil terminal Omišalj & 228 & 8 & 9,334 & 0 & 0 & 0 \\
\hline LPG terminal Sršćica & 82 & 68 & 6,689 & 1 & 1 & 20 \\
\hline Shipyard Viktor Lenac & 210 & 210 & $1,373,241$ & 11 & 0 & 0 \\
\hline Terminal Raša Bršica & 330 & 309 & 130,743 & 16 & 16 & 3.8 \\
\hline TOTAL & 3,631 & 1,874 & $5,255,031$ & 92 & 36 & \\
\hline
\end{tabular}

Table 4 - Results of the real case scenario (BWT barge)

\begin{tabular}{||c|c|c|c|c||}
\hline $\begin{array}{c}\text { No. of barge single } \\
\text { assignments }\end{array}$ & $\begin{array}{c}\text { No. of barge } \\
\text { consecutive uses }\end{array}$ & $\begin{array}{c}\text { In service barge time } \\
\text { (navigation and treating) }\end{array}$ & $\begin{array}{c}\text { BWT unit working } \\
\text { hours (treating) }\end{array}$ & $\begin{array}{c}\text { Ballast volume } \\
\text { treated (t) }\end{array}$ \\
\hline \hline 91 & 1 & $4.5 \%$ & $936 \mathrm{hrs}(3.6 \%)$ & 280,835 \\
\hline
\end{tabular}


The total ballast water discharged is $5.2 \mathrm{M}$ tons for a three-year period or $1.7 \mathrm{M}$ tons per year. The result volume is approximately 1.5 times higher than the volume estimated using Ballast Water Reporting Forms collected in the port of Rijeka. The total volume of ballast water treated on-board BWM barge is significantly smaller, i.e. 280,835 tons.

According to the results obtained, undue delays may be expected only at Raša Bršica terminal, obviously due to the great distance from lay-up berth. The other terminal where BWT barge services are often required is the Bakar terminal, where large bulk carriers are usually berthed. Taken together, in the three-year period only 36 ships have to wait for the service, out of which $45 \%$ are ships arriving at Raša Bršica terminal. It is important to note that in-service time is quite small - only $4.5 \%$ of the time.

\section{CONCLUSIONS}

As an alternative to ship-board BWT systems, a landbased, mobile-based or barge-based systems may be used. Whatever alternative system is used, it should not interfere with regular port operations, should not cause delayed handling of cargo and should be technically and economically viable. In comparison to shipboard BWT systems or land based systems, there are very few studies conducted and models developed to explore the barge-based system efficiency.

The most important advantages of barge-based BWT system are the operational autonomy and the ability to be used on different locations. It does not require any land-based pipelines or facilities and it does not interfere with other port operations. The disadvantage is the requirement that ships should be equipped with a ship-to-shore ballast water connection (it is required for any other shore-based system). Furthermore, additional operational costs and potential ship delays due to concurrent requests or low treatment capacity system installed could be expected.

Simulation presented in the paper provides frequency of BWT barge utilization, estimated working hours and ballast volume treated in multi-terminal ports. These data represent the fundamental information of barge usability.

Simulation results for the port of Rijeka case study indicate that the barge system is not viable i.e. for $84.2 \%$ of time in the worst case and $95.5 \%$ of time in real-life case scenario the barge is laid-up. Rather small barge treatment capacity $\left(300 \mathrm{~m}^{3} / \mathrm{h}\right)$ may cause delays in case of concurrent ship requests, especially in case of significant ballast volumes. Furthermore, the presence of distant terminals to be serviced by the BWT barge significantly downgrades the ships' waiting times. The advance notice for ships calling at such distant terminals is an obvious necessity to avoid long waiting times.
From the analysis of the worst case scenario it may be concluded that even in the case of arrivals of ships with significant ballast volumes, the part of the time the barge is not used is quite high. The number of concurrent or consecutive uses of BWT barge even in the worst case scenario is relatively low.

The barge could be economically efficient only in ports accommodating large number of ships requiring its service and with higher ballast volumes to discharge.

However, it is important to emphasize that ports should have an alternative reception facility, whichever type is viable, to help vessels not compliant with BWM Convention.

\section{ACKNOWLEDGEMENTS}

This publication has been produced with the financial assistance of the IPA Adriatic Cross-Border Cooperation Programme - strategic project Ballast Water Management System for Adriatic Sea Protection (BALMAS). The contents of this publication are the sole responsibility of authors and can under no circumstances be regarded as reflecting the position of the IPA Adriatic Cross-Border Cooperation Programme Authorities.

\author{
Dr. SC. LOVRO MAGLIĆ \\ E-mail: maglic@pfri.hr \\ Prof. dr. Sc. DAMIR ZEC \\ E-mail: zec@pfri.hr \\ Doc. dr. Sc. VLADO FRANČIÍ \\ E-mail: vfrancic@pfri.hr \\ Sveučilište u Rijeci, \\ Pomorski fakultet u Rijeci \\ Studentska 2, 51000 Rijeka, Hrvatska
}

\section{UČINKOVITOST TEGLENICE SA SUSTAVOM ZA OBRADU BALASTNIH VODA U LUCI S VIŠE TERMINALA}

\section{SAŽETAK}

Rad prikazuje ishode diskretne simulacije upravljanja balastnim vodama u luci s više terminala. Simulacija uključuje manevriranje brodova, operacije s teretom i balastom te rad teglenice sa sustavom za obradu balastnih voda s brodova na području svih terminala.Teglenicu sa sustavom za obradu balastnih voda koriste brodovi koji nisu u mogućnosti koristiti svoju opremu, koji nisu opremljeni odgovarajućim sustavom za obradu balastnih voda ili koji ne zadovoljavaju zahtjeve Međunarodne konvencije o nadzoru i upravljanju brodskim balastnim vodama i talozima 2004 (BWM) iz bilo kojeg razloga. Glavni je cilj procijeniti učinkovitost $i$ isplativost takvih sustava kao moguća podrška brodovima koji nisu u skladu sa zahtjevima BWM konvencije, nakon što stupi na snagu. Model je razvijen i testiran koristeći simulacijski program Arena. Ulazni parametri su temeljeni na stvarnim podacima prometa u luci Rijeka. Rezultati ukazuju da bi teglenica za obradu balastnih voda bila vrlo malo korištena te da su takvi sustavi isplativi samo u lukama u kojima se znatne količine balastnih voda iskrcavaju koristeći lučke sustave obrade. 


\section{KLUUČNE RIJEČI}

upravljanje balastnim vodama; prihvat balastnih voda; diskretna simulacija;

\section{REFERENCES}

[1] David M, Gollasch S, Pavliha M. Global ballast water management and the "same location" concept: a clear term or a clear issue?. Ecological Applications. 2013 Mar;23(2):331-338.

[2] David M, Gollasch S, Elliott B, Wiley C. Ballast Water Management Under the Ballast Water Management Convention. In: David M, Gollasch S, editors. Global Maritime Transport and Ballast Water Management: Issues and Solutions. Dordrecht: Springer Science+Business Media, 2015; p. 89-108.

[3] Brown and Coldwell. Port of Milwaukee - Onshore Ballast Water Treatment Feasibility Study Report. Milwaukee: Brown and Coldwell; 2007.

[4] Brown and Coldwell. Port of Milwaukee - Off-ship Ballast Water Treatment Feasibility Study Report. Milwaukee: Brown and Coldwell; 2008.

[5] COWI A/S. Ballast water treatment in ports - Feasibility study. Kongens Lyngby: COWI A/S; 2012.

[6] King DM, Hagan PT. Economic and Logistical Feasibility of Port-based Ballast Water Treatment: A Case Study at the Port of Baltimore (USA). Maritime Environmental Resource Centre, Ballast Water Economics Discussion Paper No. 6; 2013.

[7] Donner P. Ballast Water Treatment Ashore - Better for the Environment and for Seafarers. WMU Journal of Maritime Affairs. 2010 Oct;9(2):191-199.

[8] Pereira NN, Brinati HL. Onshore ballast water treatment: A viable option for major ports. Marine Pollution Bulletin. 2012 Nov;64:2296-2304.

[9] US Environmental Protection Agency. Efficacy of Ballast Water Treatment Systems: a report by the EPA Science Advisory Board. Washington D.C.: US Environmental Protection Agency; 2011.

[10] Cohen AN. Ships' Ballast Water and the Introduction of Exotic Organisms into the San Francisco Estuary Current Status of the Problem and Options for Management. Richmond: San Francisco Estuary Institute; 1998.

[11] David M, Perkovič M, Suban V, Gollasch S. A generic ballast water discharge assessment model as a decision supporting tool in ballast water management. Decision support systems. 2012 Apr;53(1):175-185.

[12] Suban V, Perkovič M, Bialowąs E, Mróz D. Models for determination of ballast water discharges in port of Gdynia. BalticMaster II (maritime safety across borders) EU project; 2012. 